\title{
Mobile health monitoring based studies for diabetes mellitus: a review
}

\author{
Omar AIShorman', Mahmoud Saleh Masadeh², Buthaynah AlShorman ${ }^{3}$ \\ ${ }^{1}$ Faculty of Engineering and AlShrouk Trading Company, Najran University, Najran, Saudi Arabia \\ ${ }^{2}$ Computer Engineering Department, Yarmouk University, Irbid 21163, Jordan \\ ${ }^{3}$ South Alternative Center for Physiotherapy and Rehabilitation, Najran, Saudi Arabia
}

\begin{tabular}{l} 
Article Info \\
\hline Article history: \\
Received Nov 10, 2020 \\
Revised Mar 2, 2021 \\
Accepted Mar 26, 2021 \\
\hline
\end{tabular}

\section{Keywords:}

Diabetes

IoT

Medical information

Mobile healthcare monitoring sensors

\begin{abstract}
Diabetes as a chronic disease is considered to be a serious problem not only for diabetic patients but also for caregivers, families and countries. Hazardously, as an example, $16 \%$ of the Middle East population died every year because of diabetes as it is reported by World Health Organization (WHO). Therefore, it is crucial to utilize the recent advances and technologies to find the best instrument for diabetes monitoring and management. Recently, mobile health (mHealth) technologies have a vital role in the healthcare industrial world. Undoubtedly, mHealth technologies are used to manage, track, monitor, diagnose, and prevent chronic diseases including, diabetes. Certainly, the main advantages of mHealth include a real-time and continuous monitoring with high reliability, accessibility, and availability. In addition to that, mHealth is considered to be a fast, accurate, simple, cheap, comfortable, and safe technology. Hence, the proposed study aims to review existing mHealth studies for managing, diagnosing, tracking, detecting, and predicting diabetic mellitus. Moreover, challenges and future trends of this emerging topic are also discussed
\end{abstract}

This is an open access article under the CC BY-SA license.

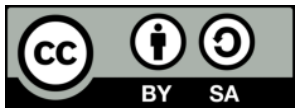

\section{Corresponding Author:}

Omar AlShorman

Faculty of Engineering and AlShrouk Trading Company

Najran University

Najran, Saudi Arabia

Email: omar2007_ahu@yahoo.com

\section{INTRODUCTION}

Globally, the number of elderly people with chronic diseases are increasing [1]-[3]. Thus, managing chronic diseases, such as diabetes, is crucial to protect the health of patients and to reduce the high cost of healthcare services [4], [5]. However, according to the World Health Organization (WHO), 16\% of the population in the Middle East died every year because of diabetes [6]. However, continuous and real-time monitoring for diabetic patients is crucial. Importantly, achieving good healthcare services for diabetic patients is a challenging task for patients and caregivers [7], [8].

Remote health monitoring (RHM) is defined as, using recent advances and modern technology for healthcare monitoring industries. As a part of RHM, mobile health (mHealth) is defined as, using smartphones, tablets and other digital assistant devices with communication technologies to provide medical services between patients and caregivers [9]. In addition, mHealth is also used to manage, track, monitor, diagnose, and prevent chronic diseases [10]. Importantly, the main benefits of mHealth include real-time continuous monitoring with high reliability, accessibility, and availability. Moreover, mHealth is considered to be, fast, accurate, simple, cheap, comfortable, and safe technology [11]. 
Recently, mHealth technologies have been extensively used for RHM for diabetic patients. Several services have been utilized, including, internet applications, short message service (SMS), and web data processing [12]. Moreover, mHealth is used to manage diabetes by managing and monitoring the dieting system, smoking, glycemic control, obesity, and physical activity [13]. Figure 1 shows the general framework of mHealth monitoring for diabetes [14].

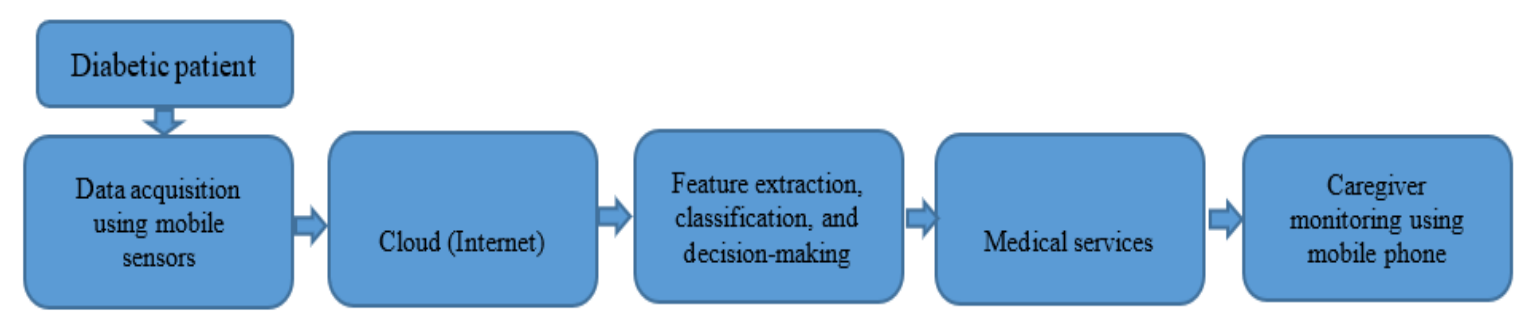

Figure 1. The framework of mhealth monitoring for diabetes

With the help of internet of things (IoT) technologies, mHealth, wirless body sensor network (WBSN), and communication generations and technologies (such as 3G, 4G, GPRS, GPS, and bluetooth) are becoming vital aspects for monitoring patients and elderlies. The proposed review study aims to highlight RHM studies for diabetic patients based on mHealth technologies. Moreover, challenges and future trends of this emerging topic are also discussed and highlighted. The rest of the paper has been organized is being as. Firstly, related works for RHM of diabetic patient's management, monitoring and tracking, as well as detecting and predicting are discussed in section 2. Challenges and possible future works are discussed in section 3 .

\section{RELATED WORK}

Recently, several studies have been conducted for RHM for diabetic patients based on mHealth technologies. These studies have focused on several related topics including diabetic management and control [15], [16], diabetes prevention [17], diabetes intervention program [18], diabetes self-efficacy [19], continuous glucose monitoring [20], glycemic control improvement [21], diabetic patients treatment [22], diabetes prediction system [23], diabetes care improvement [24], continuous and remote monitoring system [25], insulin dose management [26], and carbohydrate measurement [27]. However, Tables 1, 2, and 3 show existing mHealth studies for managing, diagnosing, tracking, detecting, and predicting diabetic mellitus, respectively. In more details, Table 1 summarizes the available related studies in the literature for RHM of diabetic patient's management based on mHealth technologies. Table 2 summarizes the available related studies in the literature for RHM of diabetic patients monitoring and tracking based on mHealth technologies. Table 3 summarizes the available related studies in the literature for RHM of diabetic patients detecting and predicting based on mHealth technologies. After reviewing several related studies, it seems that this topic still in its early stages, where more extensive future work is still needed to tackle the existing research problems. Thus, evaluating the efficiency and efficacy of mHealth based diabetes monitoring needs to be investigated more by the researches.

Table 1. mHealth related literature for RHM of diabetic patients management based on mHealth technologies

\begin{tabular}{|c|c|c|c|c|}
\hline Reference & Application & Contribution & Advantages & Drawbacks \\
\hline [29] & $\begin{array}{l}\text { Type } 2 \text { diabetes } \\
\text { management and } \\
\text { prevention }\end{array}$ & $\begin{array}{l}\text { Short message service (SMS) } \\
\text { technology to prevent and } \\
\text { manage diabetes is presented }\end{array}$ & - mHealth intervention & $\begin{array}{l}\text { - SMS technology for } \\
\text { diabetes } \\
\text { management is not } \\
\text { efficient }\end{array}$ \\
\hline$[30]$ & $\begin{array}{l}\text { Diabetes } \\
\text { management }\end{array}$ & $\begin{array}{l}\text { Self-reported mobile technology } \\
\text { system is proposed }\end{array}$ & $\begin{array}{ll}\text { - } & \text { Real time monitoring } \\
\text { - } & \text { Do-it-yourself } \\
& \text { mhealth technology }\end{array}$ & $\begin{array}{l}\text { - The usability has to } \\
\text { be improved }\end{array}$ \\
\hline$[31]$ & $\begin{array}{l}\text { Type } 1 \text { diabetes } \\
\text { management }\end{array}$ & $\begin{array}{l}\text { The efficiency of mHealth } \\
\text { applications for managing } \\
\text { diabetes is evaluated }\end{array}$ & $\begin{array}{l}\text { - Blood glucose control and } \\
\text { management }\end{array}$ & - Small sample sizes \\
\hline$[32]$ & $\begin{array}{l}\text { Cardiovascular } \\
\text { disease and Diabetes } \\
\text { management }\end{array}$ & $\begin{array}{l}\text { Self-management application for } \\
\text { diabetic patients is proposed }\end{array}$ & $\begin{array}{l}\text { - Reducing cardiometabolic } \\
\text { risk }\end{array}$ & $\begin{array}{ll}\text { - } & \text { Limited age group } \\
\text { - } & \text { Small sample sizes }\end{array}$ \\
\hline
\end{tabular}


Table 1. mHealth related literature for RHM of diabetic patients management based on mHealth technologies

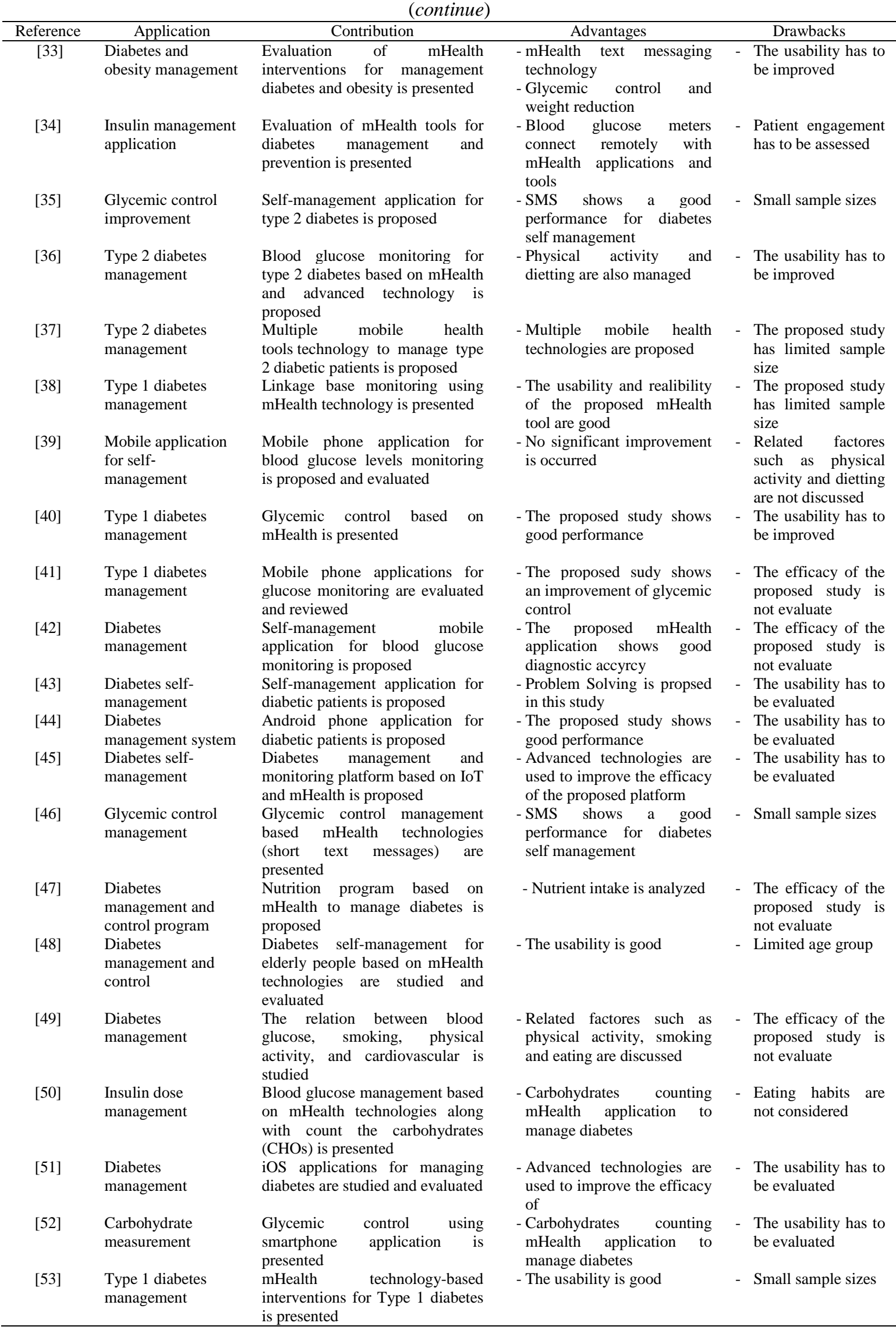


Table 1. mHealth related literature for RHM of diabetic patients management based on mHealth technologies

\begin{tabular}{|c|c|c|c|c|}
\hline Reference & Application & Contribution & Advantages & Drawbacks \\
\hline$[54]$ & $\begin{array}{l}\text { Diabetes } \\
\text { management }\end{array}$ & $\begin{array}{l}\text { Diabetes self-management for } \\
\text { elderly people in china based on } \\
\text { mHealth technologies is proposed }\end{array}$ & $\begin{array}{l}\text { - The efficacy of the proposed } \\
\text { study is evaluate }\end{array}$ & - Limited age group \\
\hline [55] & $\begin{array}{l}\text { Diabetes } \\
\text { management and } \\
\text { control }\end{array}$ & $\begin{array}{l}\text { Diabetes management and care } \\
\text { improvement based on mHealth } \\
\text { technologies are evaluated }\end{array}$ & $\begin{array}{l}\text { - The efficacy of the proposed } \\
\text { study is evaluated }\end{array}$ & - Limited age group \\
\hline [56] & $\begin{array}{l}\text { Glycemic control } \\
\text { management }\end{array}$ & $\begin{array}{l}\text { Glycemic control based on } \\
\text { mHealth for type } 1 \text { diabetic } \\
\text { patients is presented }\end{array}$ & $\begin{array}{l}\text { - Diabetes management is } \\
\text { improved and the efficacy } \\
\text { of the proposed study is } \\
\text { evaluated }\end{array}$ & $\begin{array}{l}\text { - Reliability has to be } \\
\text { improved }\end{array}$ \\
\hline [57] & $\begin{array}{l}\text { Diabetes care } \\
\text { improvement and } \\
\text { self-management }\end{array}$ & $\begin{array}{l}\text { Mobile phone applications for } \\
\text { glucose monitoring are evaluated }\end{array}$ & $\begin{array}{l}\text { - Microvascular outcomes are } \\
\text { improved }\end{array}$ & $\begin{array}{l}\text { - Reliability has to be } \\
\text { improved }\end{array}$ \\
\hline [58] & $\begin{array}{l}\text { mHealth self- } \\
\text { management }\end{array}$ & $\begin{array}{l}\text { Glycemic control based on text } \\
\text { messaging program patients is } \\
\text { presented }\end{array}$ & - Two-way SMS framework & - Small sample sizes \\
\hline [59] & $\begin{array}{l}\text { Diabetes } \\
\text { management and } \\
\text { control }\end{array}$ & $\begin{array}{l}\text { Diabetes self-management and } \\
\text { monitoring based on IoT and } \\
\text { mHealth technologies is reviewed }\end{array}$ & $\begin{array}{l}\text { - Advanced technologies are } \\
\text { used to improve the efficacy } \\
\text { of the proposed platform }\end{array}$ & $\begin{array}{l}\text { - Reliability has to be } \\
\text { improved }\end{array}$ \\
\hline$[60]$ & $\begin{array}{l}\text { Diabetes self- } \\
\text { efficacy }\end{array}$ & $\begin{array}{l}\text { Self-management application for } \\
\text { diabetic patients based on } \\
\text { mHealth technology is proposed }\end{array}$ & $\begin{array}{l}\text { - The efficacy of the proposed } \\
\text { study is evaluated }\end{array}$ & $\begin{array}{l}\text { - The usability has to } \\
\text { be evaluated }\end{array}$ \\
\hline [61] & $\begin{array}{l}\text { Diabetes self- } \\
\text { efficacy }\end{array}$ & $\begin{array}{l}\text { Self-management application for } \\
\text { diabetic patients is proposed }\end{array}$ & $\begin{array}{l}\text { - The efficacy of the proposed } \\
\text { study is evaluated }\end{array}$ & - Limited age group \\
\hline$[62]$ & $\begin{array}{l}\text { Efficacy of mHealth } \\
\text { for managing } \\
\text { diabetes }\end{array}$ & $\begin{array}{l}\text { Android phone applications for } \\
\text { managing diabetic patients are } \\
\text { summarized }\end{array}$ & $\begin{array}{l}\text { - The usability and realibility } \\
\text { are evaluated }\end{array}$ & $\begin{array}{l}\text { - Related factores } \\
\text { such as physical } \\
\text { activity smoking, } \\
\text { and dietting are not } \\
\text { discussed }\end{array}$ \\
\hline$[63]$ & $\begin{array}{l}\text { Diabetes care } \\
\text { improvement and } \\
\text { self-management }\end{array}$ & $\begin{array}{l}\text { Diabetes self-management and } \\
\text { care improvement based on } \\
\text { mHealth technologies are studied } \\
\text { and evaluated }\end{array}$ & $\begin{array}{l}\text { - The efficacy of the proposed } \\
\text { study is evaluated }\end{array}$ & - Small sample sizes \\
\hline
\end{tabular}

Table 2. mHealth related literature for RHM of diabetic patients monitoring and tracking based on mHealth technologies

\begin{tabular}{|c|c|c|c|c|}
\hline Reference & Application & Contribution & Advantages & Drawbacks \\
\hline [64] & $\begin{array}{l}\text { mHealth self- } \\
\text { monitoring }\end{array}$ & $\begin{array}{l}\text { mHealth for self-monitoring and } \\
\text { self-reported is proposed }\end{array}$ & $\begin{array}{l}\text { - Diabetes prevention } \\
\text { based program } \\
\text { technologies }\end{array}$ & $\begin{array}{l}\text { - The proposed study has } \\
\text { limited sample size }\end{array}$ \\
\hline$[65]$ & $\begin{array}{l}\text { Diabetic patients } \\
\text { remote } \\
\text { monitoring }\end{array}$ & $\begin{array}{l}\text { Utilizing internet of things (IoT) to } \\
\text { build a system for monitoring } \\
\text { glucose continuously, mHealth, fog } \\
\text { and cloud computing, and } \\
\text { blockchain is proposed }\end{array}$ & $\begin{array}{l}\text { - Advanced technologies are } \\
\text { used to improve the efficacy } \\
\text { of the proposed system }\end{array}$ & $\begin{array}{l}\text { - The usability has to be } \\
\text { evaluated and improved }\end{array}$ \\
\hline [66] & $\begin{array}{l}\text { Continuous } \\
\text { glucose } \\
\text { monitoring } \\
\text { system }\end{array}$ & $\begin{array}{l}\text { Wearable contact lens and mHealth } \\
\text { based continuous glucose } \\
\text { monitoring is presented }\end{array}$ & $\begin{array}{l}\text { - Advanced technologies are } \\
\text { used to improve the efficacy } \\
\text { of the proposed system with } \\
\text { cheap price and high } \\
\text { performance }\end{array}$ & $\begin{array}{l}\text { - The usability has to be } \\
\text { evaluated and improved }\end{array}$ \\
\hline [67] & $\begin{array}{l}\text { Continuous } \\
\text { glucose } \\
\text { monitoring } \\
\text { system }\end{array}$ & $\begin{array}{l}\text { mHealth framework based } \\
\text { continuous glucose monitoring is } \\
\text { presented }\end{array}$ & $\begin{array}{l}\text { - The proposed framework is } \\
\text { fast, cheap and accurate }\end{array}$ & $\begin{array}{l}\text { - The efficacy of the } \\
\text { proposed study has to } \\
\text { be evaluated }\end{array}$ \\
\hline [68] & $\begin{array}{l}\text { Glucose } \\
\text { monitoring and } \\
\text { expert decision } \\
\text { system }\end{array}$ & $\begin{array}{l}\text { Mobile phone blood glucose } \\
\text { monitoring is proposed and } \\
\text { evaluated }\end{array}$ & $\begin{array}{l}\text { - Advanced technologies are } \\
\text { used to improve the efficacy } \\
\text { of the proposed system }\end{array}$ & $\begin{array}{l}\text { - The usability has to be } \\
\text { evaluated and improved }\end{array}$ \\
\hline [69] & $\begin{array}{l}\text { Continuous } \\
\text { glucose } \\
\text { monitoring }\end{array}$ & $\begin{array}{l}\text { Multiple daily injections based real- } \\
\text { time continuous glucose monitoring } \\
\text { is proposed }\end{array}$ & $\begin{array}{l}\text { - The proposed continuous and } \\
\text { remote monitoring system } \\
\text { shows high performance with }\end{array}$ & $\begin{array}{l}\text { - The usability has to be } \\
\text { evaluated and improved }\end{array}$ \\
\hline [70] & $\begin{array}{l}\text { Foot pathology } \\
\text { monitoring }\end{array}$ & $\begin{array}{l}\text { Mobile application } \\
\text { "FootSnap," is developed }\end{array}$ & $\begin{array}{l}\text { - A novel mHealth application } \\
\text { for diabetic feet }\end{array}$ & $\begin{array}{l}\text { - The usability has to be } \\
\text { evaluated and improved }\end{array}$ \\
\hline [71] & $\begin{array}{l}\text { mHealth self- } \\
\text { monitoring }\end{array}$ & $\begin{array}{l}\text { A caloric-monitoring mobile } \\
\text { application to manage type } 2 \\
\text { diabetes is presented }\end{array}$ & $\begin{array}{l}\text { - } \text { Calories counting mHealth } \\
\text { application to manage } \\
\text { diabetes }\end{array}$ & $\begin{array}{l}\text { - Reliability has to be } \\
\text { evaluated }\end{array}$ \\
\hline
\end{tabular}


Table 2. mHealth related literature for RHM of diabetic patients monitoring and tracking based on mHealth technologies (continue)

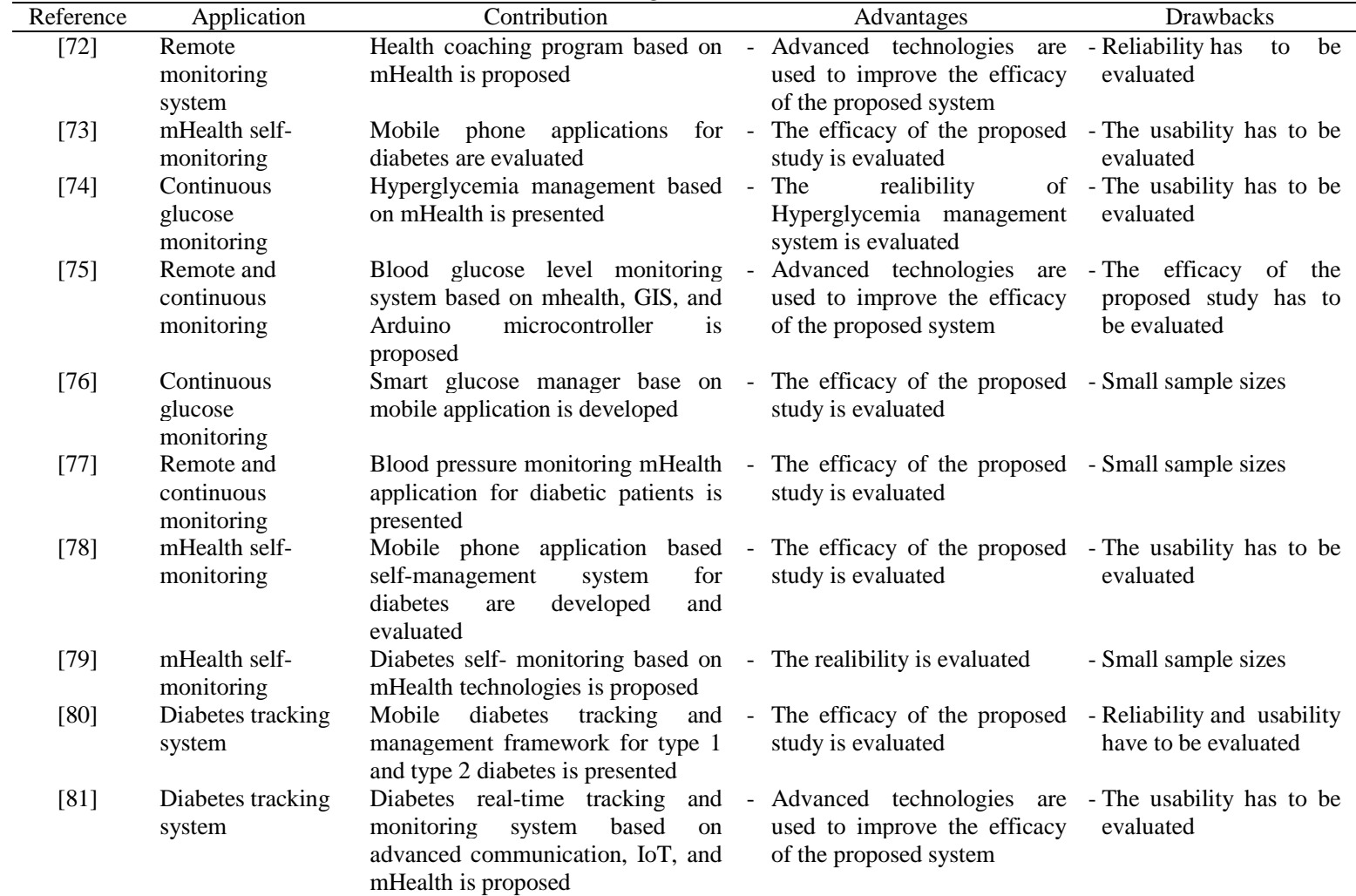

Table 3. mHealth related literature for RHM of diabetic patients detecting and predicting based on mHealth technologies

\begin{tabular}{|c|c|c|c|c|}
\hline Reference & Application & Highlight & Advantages & Drawbacks \\
\hline$[82]$ & $\begin{array}{l}\text { Diabetes } \\
\text { intervention program }\end{array}$ & $\begin{array}{l}\text { Diabetes prevention based on mHealth } \\
\text { technology is proposed }\end{array}$ & $\begin{array}{l}\text { - The efficacy of the } \\
\text { proposed study is evaluated }\end{array}$ & $\begin{array}{l}\text { - The usability has to be } \\
\text { evaluated }\end{array}$ \\
\hline [83] & $\begin{array}{l}\text { Diabetic patients' } \\
\text { treatment }\end{array}$ & $\begin{array}{l}\text { Blood glucose levels monitoring using } \\
\text { mobile applications is presented }\end{array}$ & - The realibility is evaluated & - Limited age group \\
\hline [84] & $\begin{array}{l}\text { Diabetes prediction } \\
\text { system }\end{array}$ & $\begin{array}{l}\text { Prediction model for blood glucose } \\
\text { monitoring algorithm using mobile } \\
\text { application is presented }\end{array}$ & - The realibility is evaluated & $\begin{array}{l}\text { - The usability has to be } \\
\text { evaluated }\end{array}$ \\
\hline [85] & $\begin{array}{l}\text { Diabetes care } \\
\text { improvement }\end{array}$ & $\begin{array}{l}\text { Mobile phone applications for diabetes } \\
\text { are evaluated }\end{array}$ & $\begin{array}{l}\text { - The efficacy of the } \\
\text { proposed study is evaluated }\end{array}$ & $\begin{array}{l}\text { - The usability has to be } \\
\text { evaluated }\end{array}$ \\
\hline [86] & $\begin{array}{l}\text { Diabetes prevention } \\
\text { intervention program }\end{array}$ & $\begin{array}{l}\text { Diabetes prevention platform based on } \\
\text { pedometer intervention and mHealth is } \\
\text { presented }\end{array}$ & $\begin{array}{l}\text { - Advanced technologies are } \\
\text { used to improve the } \\
\text { efficacy of the proposed }\end{array}$ & $\begin{array}{l}\text { - Reliability and } \\
\text { usability have to be } \\
\text { evaluated }\end{array}$ \\
\hline [87] & $\begin{array}{l}\text { Type } 1 \text { diabetes } \\
\text { detecting system }\end{array}$ & $\begin{array}{l}\text { Diagnosing and early detection of } \\
\text { Type } 1 \text { diabetic patients based on } \\
\text { physical activity and mHealth is } \\
\text { proposed }\end{array}$ & $\begin{array}{l}\text { - Related factores such as } \\
\text { physical are discussed }\end{array}$ & - Limited age group \\
\hline
\end{tabular}

\section{CHALLENGES AND FUTURE TRENDS}

Achieving good healthcare services for diabetic patients is a challenging task for patients and caregivers [88], [89]. Here, we summarize the main challenges and possible future trends for mHealth based diabetes monitoring:

- The effectiveness and performance of mHealth applications for monitoring diabetes have to be evaluated further [90].

- In the development stage for mHealth application, patients' safety and privacy have to be taken in consideration as a high design priority [91].

- Advanced digital technologies should be applied for diabetes healthcare industry such as insulin delivery systems and insulin pumps [92].

- Continuous glucose monitoring systems should be investigated and evaluated further [93].

- Cost-effectiveness for diabetes healthcare industry should be extensively evaluated [94] 
- Related factors with diabetics such as age, gender, pregnancy, physical inactivity, sleep, smoking, dieting system, and obesity should be investigated [95]-[97]

- Diversity of multiple devices and protocols represents a serious challenge to be addressed [98]

- User acceptability and usability, e.g., lack of patient experience on using advanced technologies is one of the main challenges [99].

- Advanced technologies such as IoT, big data analytics, neuro-fuzzy, and advanced signal and image processing should be used to develop mHelath based applications for diabetes [100]-[106].

\section{CONCLUSION}

In this era, elderly and patients with chronic health conditions, such as diabetes, require special and continous healthcare services. However, remote health monitoring (RHM) helps patients, caregivers, and healthcare society to improve healthcare services by benefiting from recent advanced technologies. Importantly, achieving good healthcare services for diabetic patients is still a challenging task. The proposed study aims to review RHM for diabetic patients based on mHealth technologies, including, diabetic management and control, diabetes prevention, diabetes intervention program, diabetes self-efficacy, continuous glucose monitoring, glycemic control improvement, diabetic patients treatment, diabetes prediction system, diabetes care improvement, continuous and remote monitoring system, insulin dose management, and carbohydrate measurement. Some of the main challenges and future trends facing this technology are also discussed. Notably, the proposed study can be considered as a report for researchers in this regard.

\section{REFERENCES}

[1] A. L. S. de Lima, T. Smits, S. K. Darweesh, G. Valenti, M. Milosevic, and M. Pijl, "Home- based monitoring of falls using wearable sensors in Parkinson's disease," Movement disorders, vol. 35, no. 1, pp. 109-115, 2020, doi: $10.1002 /$ mds. 27830 .

[2] O. M. AlShorman and A. M. Alshorman, "Frontal lobe and long-term memory retrieval analysis during prelearning stress using EEG signals," Bulletin of Electrical Engineering and Informatics (BEEI), vol. 9, pp. 141-145, 2020, doi: 10.11591/eei.v9i1.1335.

[3] O. AlShorman, T. Ali, and M. Irfan, "EEG Analysis for Pre-learning Stress in the Brain," in Asian Simulation Conference, 2017, pp. 447-455, doi: 10.1007/978-981-10-6502-6_39.

[4] S. A. Diwani and Z. O. Yonah, "A novel holistic disease prediction tool using best fit data mining techniques," International Journal of Computing and Digital Systems, vol. 6, pp. 63-72, 2017, doi: 10.12785/IJCDS/060202.

[5] D. Mahmood, A. Fadhil, and M. M. Rafaa, "IoT based on Health Caring Systems Survey," International Journal of Computing and Digital Systems, vol. 10, pp. 1-10, 2020.

[6] P. Saeedi, et al., "Mortality attributable to diabetes in 20-79 years old adults, 2019 estimates: Results from the International Diabetes Federation Diabetes Atlas," Diabetes research and clinical practice, vol. 162, p. 108086, 2020, doi: 10.1016/j.diabres.2020.108086.

[7] R. S. Istepanian and T. Al-Anzi, "m-Health 2.0: new perspectives on mobile health, machine learning and big data analytics," Methods, vol. 151, pp. 34-40, 2018, doi: 10.1016/j.ymeth.2018.05.015.

[8] E. Maini, B. Venkateswarlu, D. Marwaha, and B. Maini, "Upgrading the Performance of Machine Learning Based Chronic Disease Prediction Systems using Stacked Generalization Technique," International Journal of Computing and Digital Systems, vol. 10, pp. 1-9, 2020.

[9] T. Baniasadi, S. R. Niakan Kalhori, S. M. Ayyoubzadeh, S. Zakerabasali, and M. Pourmohamadkhan, "Study of challenges to utilise mobile-based health care monitoring systems: a descriptive literature review," Journal of telemedicine and telecare, vol. 24, pp. 661-668, 2018, doi: 10.1177\%2F1357633X18804747.

[10] E. Guillodo, et al., "Clinical Applications of Mobile Health Wearable-Based Sleep Monitoring: Systematic Review," JMIR mHealth and uHealth, vol. 8, no. 4, p. e10733, 2020.

[11] S. Dick, Y. O'Connor, and C. Heavin, "Approaches to mobile health evaluation: a comparative study," Information Systems Management, vol. 37, pp. 75-92, 2020, doi: 10.1080/10580530.2020.1696550.

[12] A. L. Fortmann, et al., "Dulce Digital: an mHealth SMS-based intervention improves glycemic control in Hispanics with type 2 diabetes," Diabetes Care, vol. 40, no. 10, pp. 1349-1355, 2017, doi: 10.2337/dc17-0230.

[13] S. Kitsiou, G. Paré, M. Jaana, and B. Gerber, "Effectiveness of mHealth interventions for patients with diabetes: an overview of systematic reviews," PloS one, vol. 12, p. e0173160, 2017, doi: 10.1371/journal.pone.0173160.

[14] O. AlShorman, B. AlShorman, M. Alkhassaweneh, and F. Alkahtani, "A Review of Internet of Medical Things (IoMT)-Based Remote Health Monitoring through Wearable Sensors: A Case Study for Diabetic Patients," Indonesian Journal of Electrical Engineering and Computer Science, vol. 20, pp. 414-422, 2020, DOI: 10.11591/ijeecs.v20.i1.pp414-422.

[15] S. Chavez, et al., "Mobile apps for the management of diabetes," Diabetes Care, vol. 40, no. 10, pp. e145-e146, 2017, doi: $10.2337 / \mathrm{dc} 17-0853$. 
[16] O. AlShorman, B. AlShorman, and F. Alkahtani, "A review of wearable sensors based monitoring with daily physical activity to manage type 2 diabetes," International Journal of Electrical \& Computer Engineering (IJEECS), vol. 11, no. 1, pp. 646-653, February 2021, DOI: 10.11591/ijece.v11i1.pp646-653.

[17] A. Michaelides, C. Raby, M. Wood, K. Farr, and T. Toro-Ramos, "Weight loss efficacy of a novel mobile Diabetes Prevention Program delivery platform with human coaching," BMJ Open Diabetes Research and Care, vol. 4, no. 1, p. e000264, 2016.

[18] D. Koot, et al., "A mobile lifestyle management program (GlycoLeap) for people with type 2 diabetes: single-arm feasibility study," JMIR mHealth and uHealth, vol. 7, no. 5, p. e12965, 2019, doi: 10.2196/12965.

[19] D. Y. Chao, T. M. Lin, and W.-Y. Ma, "Enhanced self-efficacy and behavioral changes among patients with diabetes: cloud-based mobile health platform and mobile app service," JMIR diabetes, vol. 4, no. 2, p. e11017, 2019, doi: 10.2196/11017.

[20] J. J. Rodrigues Barata, R. Munoz, R. D. De Carvalho Silva, J. J. P. C. Rodrigues, and V. H. C. De Albuquerque, "Internet of Things Based on Electronic and Mobile Health Systems for Blood Glucose Continuous Monitoring and Management," in IEEE Access, vol. 7, pp. 175116-175125, 2019, doi: 10.1109/ACCESS.2019.2956745.

[21] H. Guo, Y. Zhang, P. Li, P. Zhou, L.-M. Chen, and S.-Y. Li, "Evaluating the effects of mobile health intervention on weight management, glycemic control and pregnancy outcomes in patients with gestational diabetes mellitus," Journal of endocrinological investigation, vol. 42, pp. 709-714, 2019, doi: 10.1007/s40618-018-0975-0.

[22] B. Hartmann, C. Fottner, K. Herrmann, T. Limbourg, M. M. Weber, and K. Beckh, "Interdisciplinary treatment of diabetic foot wounds in the elderly: low risk of amputations and mortality and good chance of being mobile with good quality of life," Diabetes and Vascular Disease Research, vol. 14, pp. 55-58, 2017, doi: $10.1177 \% 2 \mathrm{~F} 1479164116666477$.

[23] M. Bhatia, S. Kaur, S. K. Sood, and V. Behal, "Internet of things-inspired healthcare system for urine-based diabetes prediction," Artificial Intelligence in Medicine, vol. 107, p. 101913, 2020, doi: 10.1016/j.artmed.2020.101913.

[24] S. Chai, D. Wang, B. Yao, L. Xu, L. Ji, and X. Zhang, "The effect of education and mobile health management on improvement of blood glucose with type 2 diabetes mellitus," Journal of Public Health, pp. 1-5, 2020, doi: 10.1007/s10389-020-01210-5.

[25] M.-A. Burckhardt, A. Roberts, G. J. Smith, M. B. Abraham, E. A. Davis, and T. W. Jones, "The use of continuous glucose monitoring with remote monitoring improves psychosocial measures in parents of children with type 1 diabetes: a randomized crossover trial," Diabetes care, vol. 41, no. 12, pp. 2641-2643, 2018, doi: 10.2337/dc180938 .

[26] H. Ding, et al., "User experience of an innovative mobile health program to assist in insulin dose adjustment: outcomes of a proof-of-concept trial," Telemedicine and e-Health, vol. 24, no. 7, pp. 536-543, 2018, doi: 10.1089/tmj.2017.0190.

[27] X. Chen, et al., "The Effects of Mobile-App-Based Low-Carbohydrate Dietary Guidance on Postprandial Hyperglycemia in Adults with Prediabetes," Diabetes Therapy, vol. 11, no. 10, pp. 2341-2355, 2020, doi: 10.1007/s13300-020-00906-x.

[28] S. Izahar, et al., "Content analysis of mobile health applications on diabetes mellitus," Frontiers in Endocrinology, vol. 8, p. 318, 2017, doi: 10.3389/fendo.2017.00318.

[29] S. Muralidharan, H. Ranjani, R. M. Anjana, S. Allender, and V. Mohan, "Mobile health technology in the prevention and management of type 2 diabetes," Indian journal of endocrinology and metabolism, vol. 21, no. 2, pp. 334-340, 2017, doi: 10.4103/ijem.IJEM_407_16.

[30] J. M. Lee, et al., "Real-world use and self-reported health outcomes of a patient-designed do-it-yourself mobile technology system for diabetes: lessons for mobile health," Diabetes technology \& therapeutics, vol. 19, no. 4, pp. 209-219, 2017, doi: 10.1089/dia.2016.0312.

[31] X. Wang, et al., "Mobile health in the management of type 1 diabetes: a systematic review and meta-analysis," BMC endocrine disorders, vol. 19, pp. 1-10, 2019, doi: 10.1186/s12902-019-0347-6.

[32] J. Hartz, L. Yingling, and T. M. Powell-Wiley, "Use of mobile health technology in the prevention and management of diabetes mellitus," Current cardiology reports, vol. 18, no. 12, pp. 1-11, 2016, doi: 10.1007/s11886-016-0796-8.

[33] Y. Wang, et al., "Effectiveness of mobile health interventions on diabetes and obesity treatment and management: systematic review of systematic reviews," JMIR mHealth and uHealth, vol. 8, no. 4, p. e15400, 2020, doi: $10.2196 / 15400$.

[34] R. Shan, S. Sarkar, and S. S. Martin, "Digital health technology and mobile devices for the management of diabetes mellitus: state of the art," Diabetologia, vol. 62, no. 6, pp. 877-887, 2019, doi: 10.1007/s00125-019-4864-7.

[35] R. Dobson, et al., "The use of mobile health to deliver self-management support to young people with type 1 diabetes: a cross-sectional survey," JMIR diabetes, vol. 2, no. 1, p. e4, 2017, doi: 10.2196/diabetes.7221.

[36] S. Goyal, et al., "The systematic design of a behavioural mobile health application for the self-management of type 2 diabetes," Canadian journal of diabetes, vol. 40, no. 1, pp. 95-104, 2016, doi: 10.1016/j.jcjd.2015.06.007.

[37] R. J. Shaw, et al., "Self-monitoring diabetes with multiple mobile health devices," Journal of the American Medical Informatics Association, vol. 27, no. 5, pp. 667-676, 2020, doi: 10.1093/jamia/ocaa007.

[38] E. A. Bellei, D. Biduski, H. R. K. Lisboa, and A. C. B. De Marchi, "Development and assessment of a mobile health application for monitoring the linkage among treatment factors of Type 1 Diabetes Mellitus," Telemedicine and e-Health, vol. 26, no. 2, pp. 205-217, 2020, doi: 10.1089/tmj.2018.0329. 
[39] Y. Yu, et al., "Effects of mobile phone application combined with or without self- monitoring of blood glucose on glycemic control in patients with diabetes: A randomized controlled trial," Journal of diabetes investigation, vol. 10, no. 5, pp. 1365-1371, 2019, doi: 10.1111/jdi.13031.

[40] S. K. Garg, V. N. Shah, H. K. Akturk, C. Beatson, and J. K. Snell-Bergeon, "Role of mobile technology to improve diabetes care in adults with type 1 diabetes: the remote-T1D study iBGStar® in type 1 diabetes management," Diabetes Therapy, vol. 8, no. 4, pp. 811-819, 2017, doi: 10.1007/s13300-017-0272-5.

[41] C. S. Sun, et al., "Improving glycemic control in adults and children with type 1 diabetes with the use of smartphone-based mobile applications: a systematic review," Canadian journal of diabetes, vol. 43, no. 1, pp. 5158. e3, 2019, DOI: 10.1016/j.jcjd.2018.03.010.

[42] S. Trawley, S. Baptista, J. L. Browne, F. Pouwer, and J. Speight, "The use of mobile applications among adults with type 1 and type 2 diabetes: results from the second MILES-Australia (MILES-2) study," Diabetes technology \& therapeutics, vol. 19, no. 12, pp. 730-738, 2017, doi: 10.1089/dia.2017.0235.

[43] Q. Ye, U. Khan, S. A. Boren, E. J. Simoes, and M. S. Kim, "An analysis of diabetes mobile applications features compared to AADE7TM: addressing self-management behaviors in people with diabetes," Journal of Diabetes Science and Technology, vol. 12, no. 4, pp. 808-816, 2018, doi: 10.1177\%2F1932296818754907.

[44] D. Machado, T. Paiva, I. Dutra, V. S. Costa, and P. Brandão, "Managing diabetes: Pattern discovery and counselling supported by user data in a mobile platform," 2017 IEEE Symposium on Computers and Communications (ISCC), Heraklion, 2017, pp. 296-299, doi: 10.1109/ISCC.2017.8024545.

[45] M. A. Al-Taee, W. Al-Nuaimy, A. Al-Ataby, Z. J. Muhsin and S. N. Abood, "Mobile health platform for diabetes management based on the Internet-of-Things," 2015 IEEE Jordan Conference on Applied Electrical Engineering and Computing Technologies (AEECT), Amman, Jordan, 2015, pp. 1-5, doi: 10.1109/AEECT.2015.7360551.

[46] B. B. Abbas, A. Al Fares, M. Jabbari, A. El Dali, and F. Al Orifi, "Effect of mobile phone short text messages on glycemic control in type 2 diabetes," International journal of endocrinology and metabolism, vol. 13, no. 1, p. e18791, 2015, doi: 10.5812/ijem.18791.

[47] J. Porter, C. E. Huggins, H. Truby, and J. Collins, "The effect of using mobile technology-based methods that record food or nutrient intake on diabetes control and nutrition outcomes: a systematic review," Nutrients, vol. 8 , no. 12 , p. 815 , 2016, doi: 10.3390/nu8120815.

[48] M. Scheibe, J. Reichelt, M. Bellmann, and W. Kirch, "Acceptance factors of mobile apps for diabetes by patients aged 50 or older: a qualitative study," Medicine 2.0, vol. 4, no. 1, p. e1, 2015, doi: 10.2196/med20.3912.

[49] H. Rehman, A. K. Kamal, S. Sayani, P. B. Morris, A. T. Merchant, and S. S. Virani, "Using mobile health (mHealth) technology in the management of diabetes mellitus, physical inactivity, and smoking," Current atherosclerosis reports, vol. 19, no. 4, p. 16, 2017, doi: 10.1007/s11883-017-0650-5.

[50] M. Anthimopoulos, J. Dehais, S. Shevchik, B. H. Ransford, D. Duke, P. Diem, et al., "Computer vision-based carbohydrate estimation for type 1 patients with diabetes using smartphones," Journal of diabetes science and technology, vol. 9, no. 3, pp. 507-515, 2015, doi: 10.1177/1932296815580159.

[51] C. A. Caburnay, K. Graff, J. K. Harris, A. McQueen, M. Smith, and M. Fairchild, "Peer Reviewed: Evaluating Diabetes Mobile Applications for Health Literate Designs and Functionality, 2014," Preventing chronic disease, vol. 12, p. e61, 2015, doi: 10.5888/pcd12.140433.

[52] M. Domhardt, M. Tiefengrabner, R. Dinic, U. Fötschl, G. J. Oostingh, and T. Stütz, "Training of carbohydrate estimation for people with diabetes using mobile augmented reality," Journal of diabetes science and technology, vol. 9, no. 3, pp. 516-524, 2015, doi: 10.1177\%2F1932296815578880.

[53] S. M. St. George, A. M. Delamater, E. R. Pulgaron, A. Daigre, and J. Sanchez, "Access to and interest in using smartphone technology for the management of type 1 diabetes in ethnic minority adolescents and their parents," Diabetes technology \& therapeutics, vol. 18, no. 2, pp. 104-109, 2016, doi: 10.1089/dia.2015.0086.

[54] C. Gao, L. Zhou, Z. Liu, H. Wang, and B. Bowers, "Mobile application for diabetes self-management in China: Do they fit for older adults?," International journal of medical informatics, vol. 101, pp. 68-74, 2017, doi: 10.1016/j.ijmedinf.2017.02.005.

[55] J. Lee, "Hype or hope for diabetes mobile health applications?," Diabetes research and clinical practice, vol. 106, no. 2, pp. 390-392, 2014, doi: 10.1016/j.diabres.2014.11.001.

[56] A. Peterson, "Improving type 1 diabetes management with mobile tools: a systematic review," Journal of diabetes science and technology, vol. 8, no. 4, pp. 859-864, 2014, doi: 10.1177\%2F1932296814529885.

[57] S. K. Garg and C. G. Parkin, "The emerging role of telemedicine and mobile health technologies in improving diabetes care," Diabetes technology \& therapeutics, vol. 21, no. s2, pp. S2-1-S2-3, 2019, doi: 10.1089/dia.2019.0090.

[58] K. Capozza, et al., "Going mobile with diabetes support: a randomized study of a text message-based personalized behavioral intervention for type 2 diabetes self-care," Diabetes Spectrum, vol. 28, no. 2, pp. 83-91, 2015, doi: 10.2337/diaspect.28.2.83.

[59] S. Deshkar, R. Thanseeh, and V. G. Menon, "A review on IoT based m-Health systems for diabetes," International Journal of Computer Science and Telecommunications, vol. 8, no. 1, pp. 13-18, 2017.

[60] H. M. Young, S. Miyamoto, M. Dharmar, and Y. Tang-Feldman, "Nurse coaching and mobile health compared with usual care to improve diabetes self-efficacy for persons with type 2 diabetes: randomized controlled trial," JMIR mHealth and uHealth, vol. 8, no. 3, p. e16665, 2020, doi: 10.2196/16665.

[61] C. C. Quinn, et al., "Mobile diabetes intervention study of patient engagement and impact on blood glucose: mixed methods analysis," JMIR mHealth and uHealth, vol. 6, no. 2, p. e31, 2018, doi: 10.2196/mhealth.9265. 
[62] X. Wu, X. Guo, and Z. Zhang, "The efficacy of mobile phone apps for lifestyle modification in diabetes: systematic review and meta-analysis," JMIR mHealth and uHealth, vol. 7, no. 1, p. e12297, 2019, doi: 10.2196/12297.

[63] L. F. Garabedian, D. Ross-Degnan, and J. F. Wharam, "Mobile phone and smartphone technologies for diabetes care and self-management," Current diabetes reports, vol. 15, no. 12, pp. 1-9, 2015, doi: 10.1007/s11892-0150680-8.

[64] M. M. MacPherson, K. J. Merry, S. R. Locke, and M. E. Jung, "Effects of Mobile Health prompts on selfmonitoring and exercise behaviors following a diabetes prevention program: secondary analysis from a randomized controlled trial," JMIR mHealth and uHealth, vol. 7, no. 9, p. e12956, 2019, doi: 10.2196/12956.

[65] T. M. Fernández-Caramés, I. Froiz-Míguez, O. Blanco-Novoa, and P. Fraga-Lamas, "Enabling the internet of mobile crowdsourcing health things: A mobile fog computing, blockchain and IoT based continuous glucose monitoring system for diabetes mellitus research and care," Sensors, vol. 19, no. 15, p. 3319, 2019, doi: $10.3390 / \mathrm{s} 19153319$.

[66] M. Elsherif, M. U. Hassan, A. K. Yetisen, and H. Butt, "Wearable contact lens biosensors for continuous glucose monitoring using smartphones," ACS nano, vol. 12, no. 6, pp. 5452-5462, 2018, doi: 10.1021/acsnano.8b00829.

[67] A. J. Jihad, S. S. Mathew, S. Paul, and D. P. Pushpalatha, "Continuous health monitoring using smartphones - A case-study for monitoring diabetic patients in UAE," 2016 12th International Conference on Innovations in Information Technology (IIT), Al Ain, United Arab Emirates, 2016, pp. 1-5, doi: 10.1109/INNOVATIONS.2016.7880027.

[68] Y. Yang, E. Y. Lee, H.-S. Kim, S.-H. Lee, K.-H. Yoon, and J.-H. Cho, "Effect of a Mobile Phone-Based GlucoseMonitoring and Feedback System for Type 2 Diabetes Management in Multiple Primary Care Clinic Settings: Cluster Randomized Controlled Trial," JMIR mHealth and uHealth, vol. 8, no. 2, p. e16266, 2020, doi: $10.2196 / 16266$.

[69] S. Chaugule and C. Graham, "Cost-effectiveness of G5 Mobile continuous glucose monitoring device compared to self-monitoring of blood glucose alone for people with type 1 diabetes from the Canadian societal perspective," Journal of medical economics, vol. 20, no. 11, pp. 1128-1135, 2017, doi: 10.1080/13696998.2017.1360312.

[70] M. H. Yap, K. E. Chatwin, C.-C. Ng, C. A. Abbott, F. L. Bowling, S. Rajbhandari, et al., "A new mobile application for standardizing diabetic foot images," Journal of diabetes science and technology, vol. 12, no. 1, pp. 169-173, 2018, doi: 10.1177/1932296817713761.

[71] G. Goh, et al., "Short-term trajectories of use of a caloric-monitoring mobile phone app among patients with type 2 diabetes mellitus in a primary care setting," Journal of medical Internet research, vol. 17, no. 2, p. e33, 2015, doi: 10.2196/jmir.3938.

[72] T. Karhula, et al., "Telemonitoring and mobile phone-based health coaching among Finnish diabetic and heart disease patients: randomized controlled trial," Journal of medical Internet research, vol. 17, no. 6, p. e153, 2015, doi: 10.2196/jmir.4059.

[73] M. Hood, R. Wilson, J. Corsica, L. Bradley, D. Chirinos, and A. Vivo, "What do we know about mobile applications for diabetes self-management? A review of reviews," Journal of behavioral medicine, vol. 39, no. 6 , pp. 981-994, 2016, doi: 10.1007/s10865-016-9765-3.

[74] M. M. Kebede, C. Schuett, and C. R. Pischke, "The role of continuous glucose monitoring, diabetes smartphone applications, and self-care behavior in glycemic control: results of a multi-national online survey," Journal of clinical medicine, vol. 8, no. 1, p. 109, 2019, doi: 10.3390/jcm8010109.

[75] Y. E. R. Julio, "Development of a Prototype Arduino-Mobile in Area of Telemedicine for Remote Monitoring Diabetic People (MAY 2015)," 2015 Asia-Pacific Conference on Computer Aided System Engineering, Quito, Ecuador, 2015, pp. 36-40, doi: 10.1109/APCASE.2015.14

[76] K. C. Gunawardena, R. Jackson, I. Robinett, L. Dhaniska, S. Jayamanne, and S. Kalpani, "The influence of the smart glucose manager mobile application on diabetes management," Journal of Diabetes Science and Technology, vol. 13, no. 1, pp. 75-81, 2019, doi: 10.1177/1932296818804522.

[77] A. Banerjee, R. A. Ramanujan, and S. Agnihothri, "Mobile Health Monitoring: Development and Implementation of an App in a Diabetes and Hypertension Clinic," 2016 49th Hawaii International Conference on System Sciences (HICSS), Koloa, HI, USA, 2016, pp. 3424-3436, doi: 10.1109/HICSS.2016.427.

[78] H. Holmen, et al., "A mobile health intervention for self-management and lifestyle change for persons with type 2 diabetes, part 2: one-year results from the Norwegian randomized controlled trial RENEWING HEALTH," JMIR mHealth and uHealth, vol. 2, no. 4, p. e57, 2014, doi: 10.2196/mhealth.3882.

[79] S. Nundy, C.-Y. E. Lu, P. Hogan, A. Mishra, and M. E. Peek, "Using patient-generated health data from mobile technologies for diabetes self-management support: provider perspectives from an academic medical center," Journal of diabetes science and technology, vol. 8, no. 1, pp. 74-82, 2014, doi: 10.1177/1932296813511727.

[80] R. Offringa, T. Sheng, L. Parks, M. Clements, D. Kerr, and M. S. Greenfield, "Digital diabetes management application improves glycemic outcomes in people with type 1 and type 2 diabetes," Journal of diabetes science and technology, vol. 12, no. 3, pp. 701-708, 2018, doi: 10.1177/1932296817747291.

[81] S. Chang, R. Chiang, S. Wu and W. Chang, "A Context-Aware, Interactive M-Health System for Diabetics," in IT Professional, vol. 18, no. 3, pp. 14-22, May-June 2016, doi: 10.1109/MITP.2016.48.

[82] S. Muralidharan, et al., "Mobile health technology (mDiab) for the prevention of type 2 diabetes: protocol for a randomized controlled trial," JMIR research protocols, vol. 6, no. 12, p. e242, 2017, doi: 10.2196/resprot.8644.

[83] J. Pavlas, O. Krejcar, P. Maresova, and A. Selamat, "Prototypes of user interfaces for mobile applications for patients with diabetes," Computers, vol. 8, p. 1, no. 1, 2019, doi: 10.3390/computers8010001. 
[84] E. Pustozerov, P. Popova, A. Tkachuk, Y. Bolotko, Z. Yuldashev, and E. Grineva, "Development and evaluation of a mobile personalized blood glucose prediction system for patients with gestational diabetes mellitus," JMIR mHealth and uHealth, vol. 6, no. 1, p. e6, 2018, doi: 10.2196/mhealth.9236.

[85] M. Shahid, S. A. Mahar, S. Shaikh, and Z. Shaikh, "Mobile phone intervention to improve diabetes care in rural areas of Pakistan: a randomized controlled trial," Journal Coll Physicians Surg Pak, vol. 25, no. 3, pp. 166-171, 2015.

[86] Y. Fukuoka, C. L. Gay, K. L. Joiner, and E. Vittinghoff, "A novel diabetes prevention intervention using a mobile app: a randomized controlled trial with overweight adults at risk," American journal of preventive medicine, vol. 49, no. 2, pp. 223-237, 2015, doi: 10.1016/j.amepre.2015.01.003.

[87] A. Czmil, S. Czmil, and D. Mazur, "A Method to Detect Type 1 Diabetes Based on Physical Activity Measurements Using a Mobile Device," Applied Sciences, vol. 9, no. 12, p. 2555, 2019, doi: 10.3390/app9122555.

[88] J. Furler, et al., "Use of professional-mode flash glucose monitoring, at 3-month intervals, in adults with type 2 diabetes in general practice (GP-OSMOTIC): a pragmatic, open-label, 12-month, randomised controlled trial," The Lancet Diabetes \& Endocrinology, vol. 8, no. 1, pp. 17-26, 2020, doi: 10.1016/S2213-8587(19)30385-7.

[89] A. Rghioui, J. Lloret, M. Harane, and A. Oumnad, "A Smart Glucose Monitoring System for Diabetic Patient," Electronics, vol. 9, no. 4, p. 678, 2020, doi: 10.3390/electronics9040678.

[90] A. Triantafyllidis, H. Kondylakis, K. Votis, D. Tzovaras, N. Maglaveras, and K. Rahimi, "Features, outcomes, and challenges in mobile health interventions for patients living with chronic diseases: A review of systematic reviews," International Journal of Medical Informatics, vol. 132, p. 103984, 2019, doi: 10.1016/j.ijmedinf.2019.103984.

[91] L. Nurgalieva, D. O’Callaghan and G. Doherty, "Security and Privacy of mHealth Applications: A Scoping Review," in IEEE Access, vol. 8, pp. 104247-104268, 2020, doi: 10.1109/ACCESS.2020.2999934.

[92] G. A. Fleming, J. R. Petrie, R. M. Bergenstal, R. W. Holl, A. L. Peters, and L. Heinemann, "Diabetes digital app technology: benefits, challenges, and recommendations. A consensus report by the European Association for the Study of Diabetes (EASD) and the American Diabetes Association (ADA) Diabetes Technology Working Group," Diabetes care, vol. 43, no. 1, pp. 250-260, 2020, doi: 10.2337/dci19-0062.

[93] S. Kriventsov, A. Lindsey, and A. Hayeri, "The Diabits App for Smartphone-Assisted Predictive Monitoring of Glycemia in Patients With Diabetes: Retrospective Observational Study," JMIR diabetes, vol. 5, no. 3, p. e18660, 2020, doi: 10.2196/18660.

[94] S. Tsuji, et al., "Cost-Effectiveness of a Continuous Glucose Monitoring Mobile App for Patients With Type 2 Diabetes Mellitus: Analysis Simulation," Journal of Medical Internet Research, vol. 22, no. 9, p. e16053, 2020, doi:10.2196/16053.

[95] S. B. Overdijkink, A. V. Velu, A. N. Rosman, M. D. Van Beukering, M. Kok, and R. P. Steegers-Theunissen, "The usability and effectiveness of mobile health technology-based lifestyle and medical intervention apps supporting health care during pregnancy: systematic review," JMIR mHealth and uHealth, vol. 6, no. 4, p. e109, 2018, doi:10.2196/mhealth.8834.

[96] N. Sukumar, et al., "Baby Steps-a structured group education programme with accompanying mobile web application designed to promote physical activity in women with a history of gestational diabetes: study protocol for a randomised controlled trial," Trials, vol. 19, no. 1, pp. 1-12, 2018, doi: 10.1186/s13063-018-3067-8.

[97] O. AlShorman, B. Alshorman, and M. Masadeh, "A Review of Physical Human Activity Recognition Chain Using Sensors," Indonesian Journal of Electrical Engineering and Informatics (IJEEI), vol. 8, no. 3, pp. 560-573, 2020, DOI: 10.11591/ijeei.v8i3.2312

[98] A. Rghioui and A. Oumnad, "Challenges and Opportunities of Internet of Things in Healthcare," International Journal of Electrical \& Computer Engineering, vol. 8, no. 5, pp. 2753-2761, October 2018, DOI: 10.11591/ijece.v8i5.pp2753-2761.

[99] S. Jusoh, "A survey on trend, opportunities and challenges of mHealth apps," International Journal of Interactive Mobile Technologies (iJIM), vol. 11, no. 6, pp. 73-85, 2017, doi: 10.3991/ijim.v11i6.7265.

[100] M. Al-khassaweneh and O. AlShorman, "Frei-Chen bases based lossy digital image compression technique," Applied Computing and Informatics, 2020, doi: 10.1016/j.aci.2019.12.004.

[101] S. Kato, et al., "Effectiveness of Lifestyle Intervention Using the Internet of Things System for Individuals with Early Type 2 Diabetes Mellitus," Internal Medicine, vol. 59, no. 1, pp. 45-53, 2020, doi: 10.2169/internalmedicine.3150-19.

[102] M. Duplaga, and A. Tubek. "mHealth-areas of application and the effectiveness of interventions," Public Health Management/Zdrowie Publiczne i Zarządzanie 16, no. 3, 2018.

[103] M. Masadeh, O. AlShorman and A. R. H. Alhawari, "A Machine Learning-based Error Model for Quality Control of Functional Approximate Computing," 2020 International Conference on Data Analytics for Business and Industry: Way Towards a Sustainable Economy (ICDABI), Sakheer, Bahrain, 2020, pp. 1-5, doi: 10.1109/ICDABI51230.2020.9325594.

[104] B. Guragai, O. AlShorman, M. Masadeh and M. B. B. Heyat, "A Survey on Deep Learning Classification Algorithms for Motor Imagery," 2020 32nd International Conference on Microelectronics (ICM), Aqaba, Jordan, 2020, pp. 1-4, doi: 10.1109/ICM50269.2020.9331503.

[105] O. AlShorman, "Medical image compression technique for telemedicine applications," ARPN Journal of Engineering and Applied Sciences, vol. 15, no. 18, pp. 2017-20123, 2020.

[106] A. Ghasempour, "Internet of things in smart grid: Architecture, applications, services, key technologies, and challenges," Inventions, vol. 4, no. 1, p. 22, 2019, doi: 10.3390/inventions4010022. 